\title{
Permineralized conifer-like leaves from the Jurassic of Patagonia (Argentina) and its paleoenvironmental implications
}

\author{
GEORGINA M. DEL FUEYO ${ }^{1}$, SILVIA C. GNAEDINGER ${ }^{2}$, MAITEN \\ A. LAFUENTE DIAZ ${ }^{1}$ and MARTÍN A. CARRIZO ${ }^{1}$
}

\author{
${ }^{1}$ Museo Argentino de Ciencias Naturales “Bernardino Rivadavia”, CONICET, División Paleobotánica, \\ Av. Ángel Gallardo, 470, C1405DJR Ciudad Autónoma de Buenos Aires, Argentina \\ ${ }^{2}$ Centro de Ecología Aplicada del Litoral, Área de Paleontología, Facultad de Ciencias Exactas y Naturales y \\ Agrimensura, Universidad Nacional del Nordeste, Ruta 5, Km 2,5, Casilla Correo 291, 3400 Corrientes, Argentina \\ Manuscript received on April 16, 2018; accepted for publication on September 26, 2018
}

\begin{abstract}
How to cite: DEL FUEYO GM, GNAEDINGER SC, LAFUENTE DIAZ MA AND CARRIZO MA. 2019. Permineralized conifer-like leaves from the Jurassic of Patagonia (Argentina) and its paleoenvironmental implications. An Acad Bras Cienc 91: e20180363. DOI 10.1590/0001-3765201920180363.

Abstract: Anatomically preserved conifer-like leaves from the Middle Jurassic La Matilde Formation at the Barda Blanca locality in the Gran Bajo de San Julián area, southern Patagonia are described here. Leaves are assigned to conifers based on the following foliar features: thick-walled epidermal cells, a sclerenchymatic hypodermis, resin canals and transfusion tracheids associated with the vascular bundle. General mesophyll anatomy and inferred foliar morphology suggest a similarity to large, broad, linearlanceolate, multi-veined conifer-like leaves. The general foliar habit indicates an affinity with the large, multi-veined leaves of the Araucariaceae; especially with those exhibited by the species of the Araucaria sections, Araucaria and Bunya. Anatomically, the permineralized leaves exhibit xeromorphic foliar features, including thick-walled epidermal cells, an isobilateral mesophyll with well-developed palisade cells and mechanical tissue. The general leaf anatomy shown by the Patagonian specimens along with sedimentological data may suggest that during the deposition of the La Matilde Formation at the Barda Blanca locality, the parent plant was well adapted to the environmental conditions, which probably consisted of a high light intensity with an adequate quantity of water in the soil, which increased the maximum leaf conductance of $\mathrm{CO}_{2}$.
\end{abstract}

Key words: conifers, Jurassic, La Matilde Formation, leaves, Patagonia, permineralized.

\section{INTRODUCTION}

The Jurassic sediments of southern Patagonia yield plenty of petrified plant fossils that comprise wellpreserved filicean stems, gymnosperm woods and

Correspondence to: Georgina Marisa Del Fueyo

E-mail: georgidf@yahoo.com.ar

ORCID: https://orcid.org/0000-0001-6776-2673

* Contribution to the centenary of the Brazilian Academy of Sciences. reproductive conifer structures. Of note is the world renowned petrified forest of the Middle Jurassic La Matilde Formation at the Monumento Natural Bosques Petrificados locality, which has become famous for its high amount and enormous in situ trunks as well as fallen logs, which have been assigned to Agathoxylon matildense (Zamuner and Falaschi 2005). Furthermore, the finding of numerous large logs that show branches of all order 
allowed Falaschi et al. (2011) to suggest that these Araucariaceae trees were composed of a main, orthotropic stem bearing up to seven plagiotropic branches in pseudowhorls. In addition, the outer bark anatomy of some of these trees has revealed a conspicuously banded periderm structure (Singer and Archangelsky 1958, Hibbett et al. 1997).

The outcrops of the La Matilde Formation at the Gran Bajo de San Julián area contain a rich and diverse petrified plant assemblage that includes stems of Millerocaulis and Osmundacaulis of the Osmundales (Herbst 2001, 2003) and trunks of Ginkgomyeloxylon of the Ginkgoales (Gnaedinger 2012) and of several conifers. Within this last group, the Podocarpaceae is well-represented by Podocarpoxylon, Circoporoxylon and Circoporopitys (Gnaedinger 2007a), whereas the Araucariaceae are represented by several species of Agathoxylon (Kloster and Gnaedinger 2018), the Cupressaceae by Protelicoxylon and Herbstiloxylon (Gnaedinger 2007b), and the Taxaceae by Prototaxoxylon (Gnaedinger and Herbst 2006).

Records of petrified fertile structures found in the La Matilde Formation at the Monumento Natural Bosques Petrificados locality are restricted to conifers. Of them, Masculostrobus altoensis is a pollen cone with helically arranged microsporophylls that show, due to poor preservation, an unknown arrangement and number of microsporangia, making the assignment to a conifer family difficult (Menéndez 1960). Among seed cones, those of Pararaucaria patagonica, previously described by Calder (1953) and Stockey (1977), were anatomically reinvestigated by Escapa et al. (2012). These authors found a seedenclosing pocket of ovuliferous scale tissue and a trilobed ovuliferous scale and thus included the cones within the Cheirolepidiaceae. However, the best preserved and exquisitely petrified seed cones belong to Araucaria mirabilis, which are assigned to the Section Bunya of Araucaria. These include first-year cones that show several development stages and mature cones with embryos (Spegazzini 1924, Stockey 1978).

Additionally, several other remains have been reported in the petrified forest, including the common Dematiaceae saprophyte fungus, Paleopericonia frietzschei, which are found in some of the Araucaria mirabilis cones (Ibáñez and Zamuner 1996), abundant araucarian-like woody seedlings, and what are believed to be aerial lignotubers borne in the axils of leaves (Taylor et al. 2009).

Despite the abundant and diverse petrified plant fossils found in the sediments of the $\mathrm{La}$ Matilde Formation, remains of leafy branches are limited to Araucarites sanctaecrucis. These fossils are based on petrified woody branches with spirally rhomboidal, imbricate and appressed leaves, which do not show any preserved internal tissues (Spegazzini 1924, Calder 1953).

The occurrence of Mesozoic permineralized leaves in Patagonia is very rare. These include the unusual hot spring chert deposits from the La Matilde Formation and the Middle-Late Jurassic Chon Aike Formation, where permineralized scale leaves with preserved foliar tissues, belonging to araucarian-type and cycadophyte leaves, have been recorded, although they have not been fully described (Channing et al. 2007, García Massini et al. 2016).

The only other record includes permineralized conifer-like leaves with anatomically preserved tissues, which are herein described from the La Matilde Formation in the area of Gran Bajo de San Julián in southern Patagonia. The general mesophyll anatomy and the inferred foliar morphology suggest a similarity to large, broad, linear-lanceolate, multi-veined conifer-like leaves. Although it is difficult to assign these leaves to any conifer family, the general foliar habit indicates a certain affinity to the leaves of the Araucariaceae, especially to those exhibited by the species of the Araucaria sections, Araucaria and Bunya. 


\section{MATERIALS AND METHODS}

The leaves studied here are preserved in blocks of permineralized coal balls collected by one of the authors (SG) in 1998 from the La Matilde Formation at the Barda Blanca locality (Estancia Meseta Chica) in the Gran Bajo de San Julián area, Santa Cruz Province, Argentina (Fig. 1). The La Matilde Formation and the Chon-Aike Formation are included in the Bahía Laura Group, a wellknown volcaniclastic rock complex that is widely distributed in the province of Santa Cruz (De Barrio et al. 1999). According to Panza and Irigoyen (1995) the base of the Bahía Laura Group is either the Roca Blanca Formation (Lower Jurassic) or the Bajo Pobre Formation (probably Aalenian-Bajocian), whereas the top constitutes the "brown clays series" (San Julián Formation), which have been assigned to the Tertiary due to its content of angiosperm leaves (De Giusto 1955, Bertels 1977, De Giusto et al. 1980). Although the age of the Bahía Laura Group is still controversial, some authors have used radiometric dating from the La Matilde and Chon-
Aike Formations to provide an age of between 157 and $162 \mathrm{Ma} \pm 5-10 \mathrm{Ma}$; indicating the BathonianCallovian interval (Spalletti et al.1982, De Barrio 1993, Echeveste et al. 2001).

The La Matilde Formation in the Gran Bajo de San Julián area comprises approximately 70$80 \mathrm{~m}$ of tuffs, including sandy tuffites, lithic tuffs (tufolites) and chonites with varied coloration, which are generally in tabular strata with very subordinate amounts of fine conglomerates. Carbonaceous pelitic levels, up to true coals, are generally located near the base of the sequence and crop out in particular at the Barda Blanca locality, where the leaves described herein were found. In these levels, abundant wood and some other fossils such as conchostracans, pelecypods, insects and anurans have also been recorded (Stipanicic and Reig 1957, Gallego 1994, Morton and Herbst 2001, Báez and Nicoli 2004, Gnaedinger 2007a).

Acetate peels were prepared by standard techniques after etching the cut and polished coal ball surfaces in 48\% hydrofluoric acid (Galtier and Phillips 1999). Selected peels were then mounted

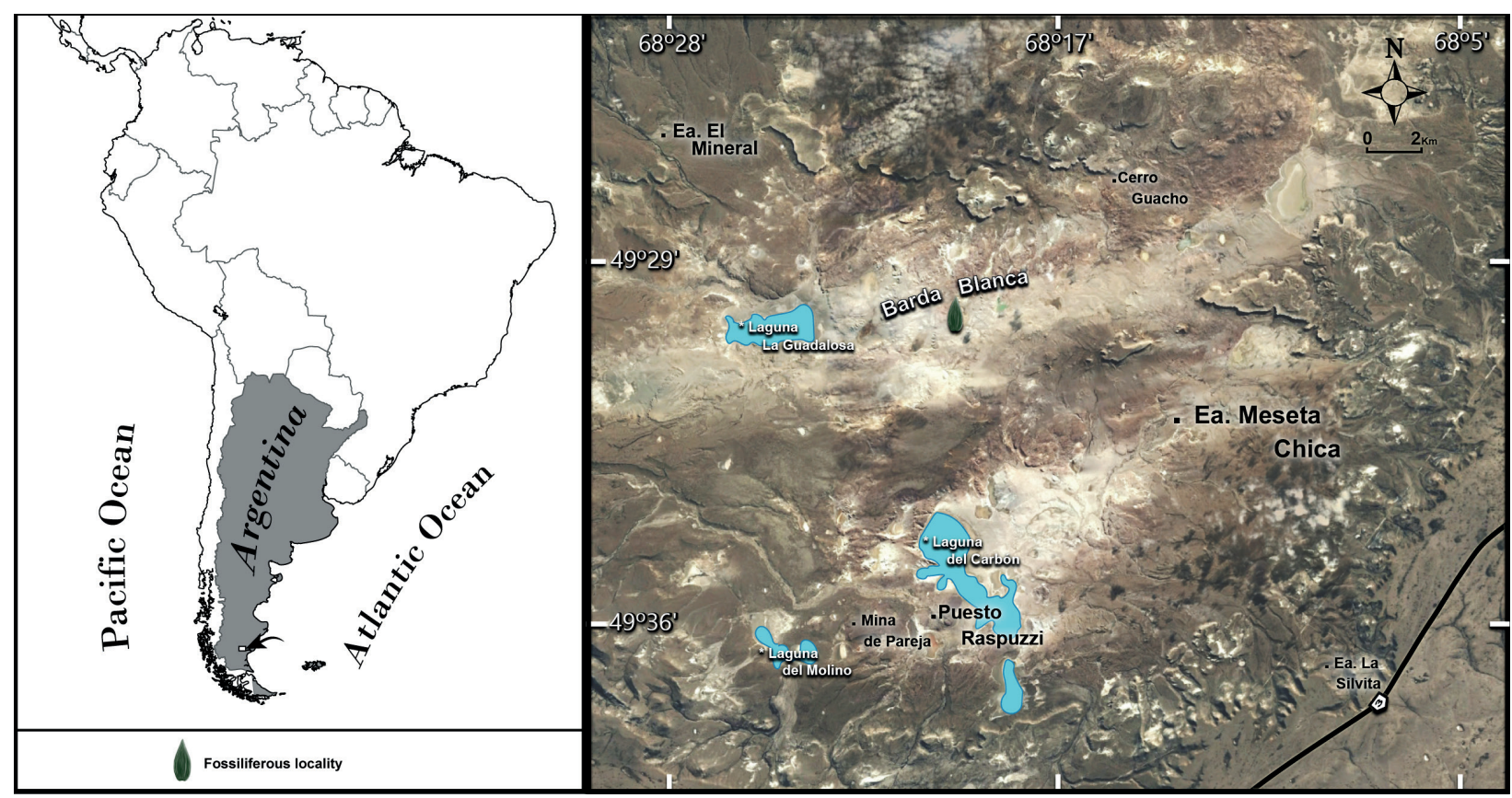

Figure 1 - Location map showing the Barda Blanca fossiliferous locality, Santa Cruz Province, Argentina. 
on microscope slides for photomicrography. Comparative material for the three species of Araucaria, A. angustifolia, A. bidwillii and $A$. araucana, were collected from cultivated individuals growing in two distinct areas. The two former taxa were collected from the Parque Centenario garden near the Museo Argentino de Ciencias Naturales "Bernardino Rivadavia" in Buenos Aires Province, and the later taxon in Bariloche City, Río Negro Province. Leaves were fixed in formalin-acetic alcohol (FAA), dehydrated in a graded ethanol series, embedded in Paramat, sectioned at approximately $10 \mu \mathrm{m}$ and stained in safranin-fast green (O’Brien and McCulley 1981). In addition, young stems of $A$. angustifolia were sectioned in tangential and radial views using a sledge microtome and stained in safranin. Fossil and extant materials were observed with a Leica DM2500, and micrographs were taken with a Leica DFC 280 and a Leica ICC50.

The recent systematic treatment of Christenhusz et al. (2011) for extant gymnosperms was taken into consideration. However, for fossil conifers, the study followed the supra-generic systematic treatment outlined in Taylor et al. (2009).

Specimens and microscope slides are deposited in the paleontological collections of the Universidad Nacional del Nordeste (UNNE) "Dr. Rafael Herbst" Paleobotany Section; Corrientes, Argentina under the acquisition numbers CTES-PB 14241a and CTES-PMP 3554a, respectively.

\section{RESULTS}

\section{SYSTEMATIC PALEOBOTANY}

Subclass PINIDAE Cronquist, Takhtajan and Zimmermann 1966

Order CONIFERALES sensu Taylor, Taylor and Kring 2009

Family Incertae sedis
Description. The description is based on permineralized packs of solitary conifer-like leaves, up to 15 preserved in longitudinal or obliqueparadermal sections (Fig. 2a, b). The largest is 6.3 $\mathrm{mm}$ long and $0.8 \mathrm{~mm}$ deep, and the smallest is 2.7 $\mathrm{mm}$ long and $0.9 \mathrm{~mm}$ deep (Fig. 2a, c). Two of the smallest specimens are incomplete and appear to be transversally and obliquely oriented and probably represent apical portions of leaves. These sections are somewhat semi-circular in outline and reach approximately 0.8 to $1.2 \mathrm{~mm}$ in diameter (Figs. 2a, 4d). Several leaf epidermal or mesophyll features are difficult to recognize due to poor preservation. However, several significant anatomical characters were accurately identified in some of the leaves. Because all of the specimens show the same anatomical details, it is assumed that they belong to the same type of conifer-like leaf. The presence of conspicuous, well-developed palisade tissue and hypodermal fiber layers indicate that the leaves are all mature.

The foliar epidermis in most of the specimens is difficult to recognize and is usually preserved in patches of paradermal views, with a few cases preserved in longitudinal section. The epidermal cells are mostly elongate, rectangular and reach $28 \mu \mathrm{m}$ long and $15.5 \mu \mathrm{m}$ wide, although some are quadrangular and reach $24 \mu \mathrm{m}$ long and 20 to 24 $\mu \mathrm{m}$ wide (Fig. 3e). Anticlinal cell walls are straight, smooth and $14 \mu \mathrm{m}$ deep, whereas periclinal walls are $8.8 \mu \mathrm{m}$ thick (Fig. 3f). Stomatal apparatuses are difficult to identify; however, what appear to be sub-stomatal chambers can be distinguished in both adaxial and abaxial surfaces. These chambers are approximately $111.4 \mu \mathrm{m}$ long and $113 \mu \mathrm{m}$ wide and can be discerned as irregularly elongate empty areas between palisade parenchyma (Figs. 2c-e, 3a, c). In only one case have the remains of a guard cell in longitudinal view been recognized, which show only one entire rounded extreme because the opposite extreme is missing. The guard cell extreme has a conspicuous periclinal wall $6.4 \mu \mathrm{m}$ thick, 

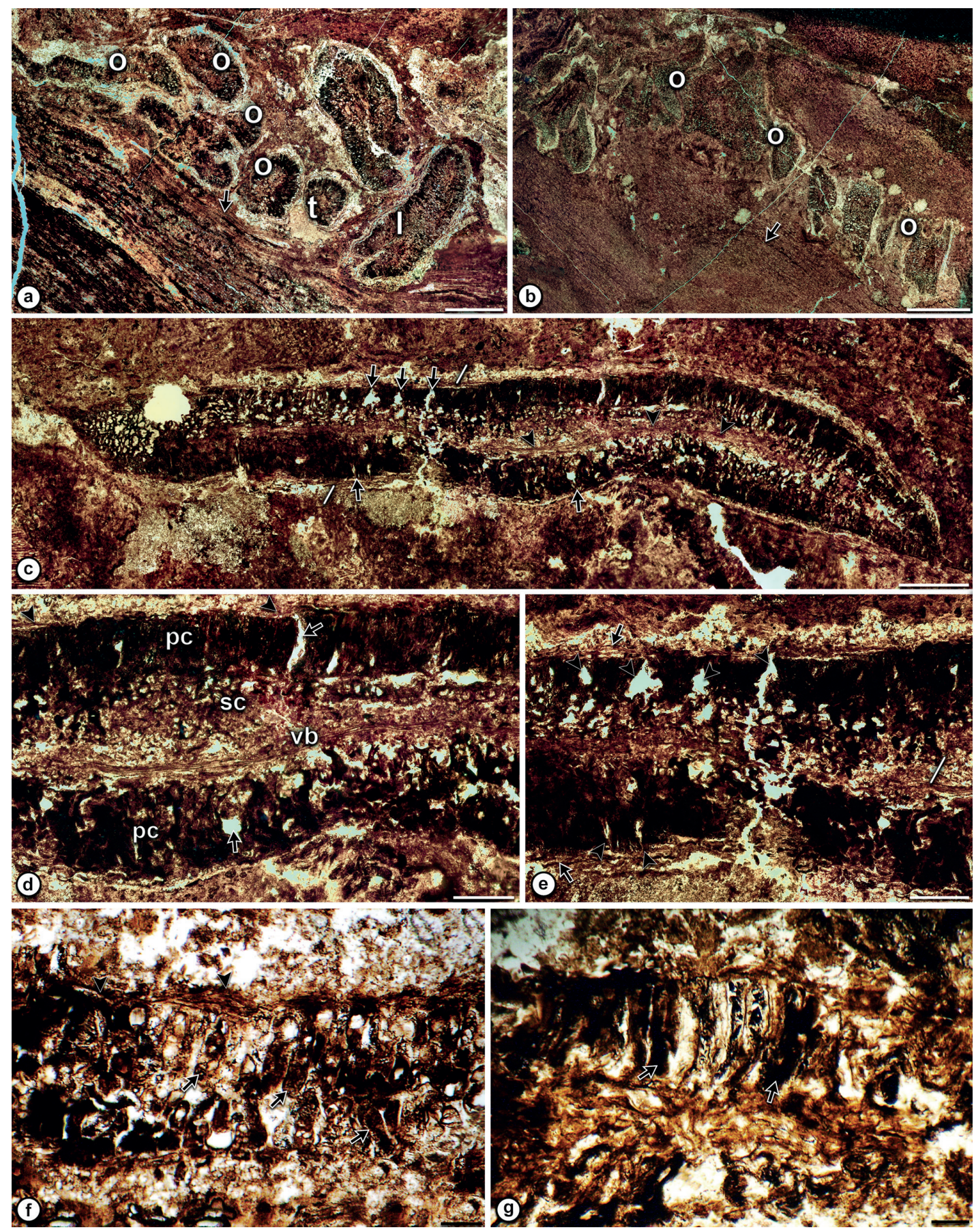

Figure 2 - Permineralized conifer-like leaves. (a-b) Packs of solitary leaves preserved in longitudinal (1), transverse (t) and oblique sections (o). Note associated conifer-like stems (arrows); in tangential section in A, in radial section in B. Bar scales A =1 mm; B = $2 \mathrm{~mm}$. (c-g) Leaf in longitudinal section. (c) Leaf showing isobilateral mesophyll, stomata in both surfaces (arrows), vascular bundle (arrow heads) and layers of hypodermal fiber (bars). On the left the section turns rather oblique. Bar scale $=500 \mu \mathrm{m}$. (d) Leaf showing densely packed palisade parenchyma cells (pc), damaged spongy parenchyma cells (sc), vascular bundle (vb), layers of hypodermal fiber (arrow heads) and sub-stomatal chambers (arrows). Bar scale $=200 \mu \mathrm{m}$. (e) Leaf showing discontinuous layers of hypodermal fiber (arrows) and sub-stomatal chambers (arrow heads). Note collapsed vascular bundle (Bar). Bar scale $=200 \mu \mathrm{m}$. (f-g) Detail of palisade parenchyma. Note dark contents (arrows). Bar scales $=50 \mu \mathrm{m}$. (f) Two cells thick. Arrow head indicates probably preserved fiber layers. g. One cell thick. 

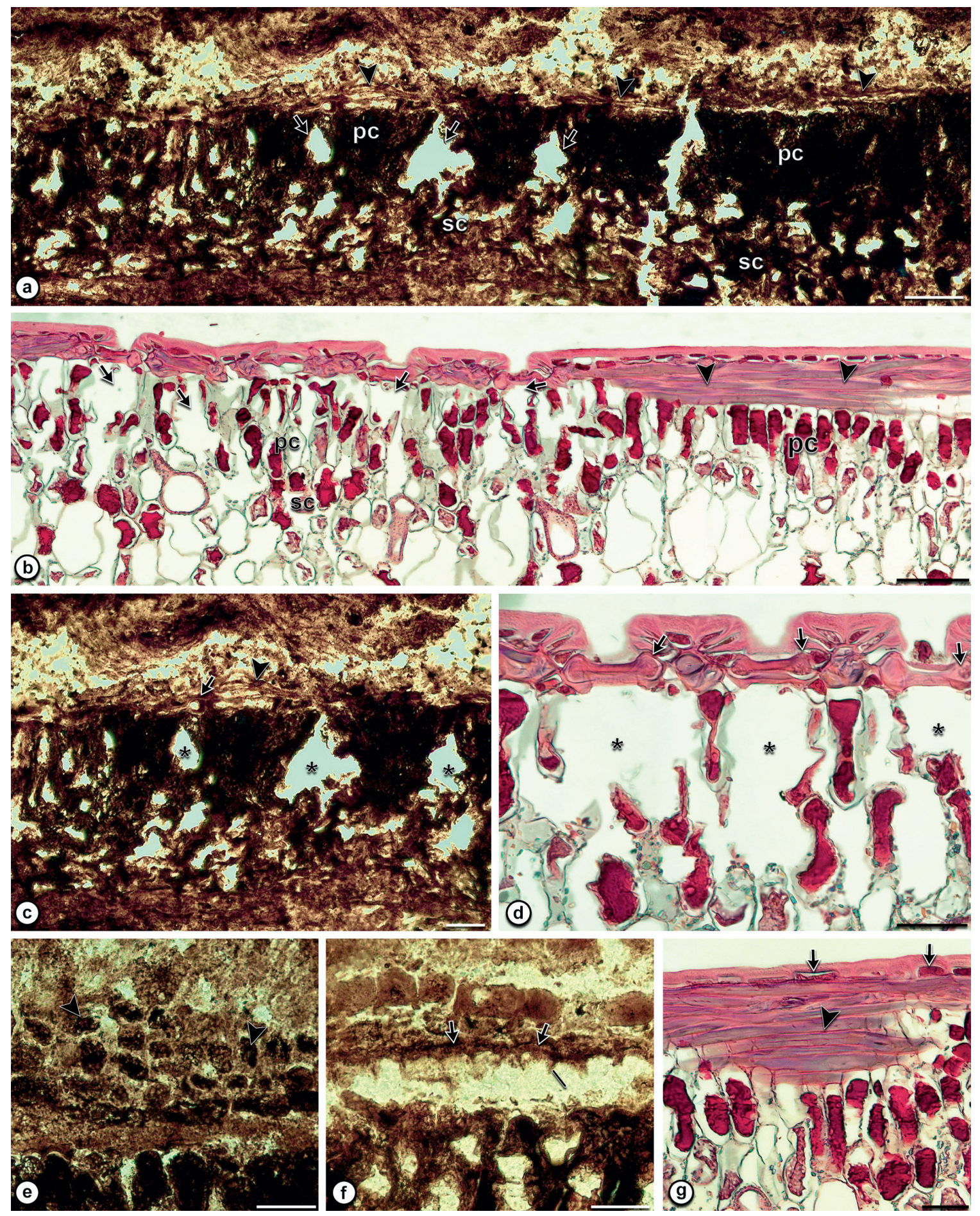

Figure 3 - Permineralized conifer-like leaf and comparative leaf of extant Araucaria araucana. (a-g). Longitudinal section. (a, c, e, f) Fossil leaf. (b, d, g) Extant leaf. (a-b) Leaves showing palisade parenchyma cells (pc), spongy parenchyma cells (sc), sub-stomatal chambers (arrows) and layers of hypodermal fibers (arrow heads) Bar scale $=100$ $\mu \mathrm{m}$. (c-d) Details of stomata (arrows) and sub-stomatal chambers (asterisks). Arrow head indicates layers of hypodermal cell. Bar scale $=50 \mu \mathrm{m}$. (e-g) Details of epidermal cells. Bar scales $=50 \mu \mathrm{m}$. (e) Epidermal cells preserved in patches in paradermal view (arrow heads). (f-g) Epidermal cells in longitudinal view (arrows). Note anticlinal walls (bar) and layers of hypodermal fibers (arrow head). 
the middle part of which is thin, reaching $3 \mu \mathrm{m}$ thick (Fig. 3c). Contiguous to the epidermis, three to four hypodermal fiber layers are preserved in longitudinal view with an incomplete length of 214 $\mathrm{mm}$ long and $13 \mathrm{~mm}$ wide (Fig. 2c-f). In transversal view, section fibers are $22 \mu \mathrm{m}$ in diameter. It appears that the second, third and fourth layers are discontinuous. In most cases due to preservation, the hypodermal cell layers appear detached from the epidermal cells (Fig. 3f).

The mesophyll is isobilateral with adaxial and abaxial palisade layers organized into one to two parenchymal cell thicknesses (Fig. 2c, f, g). These cells are elongate rectangular, $102 \mu \mathrm{m}$ long and $25 \mu \mathrm{m}$ wide, with blunt ends and appear densely packed, especially along the abaxial side where the individual cells are difficult to recognize. Most of the palisade cells are full of a dark material that can probably be attributed to resins. In between are spongy parenchymal cells that are somewhat isodiametric in shape and up to $54 \mu \mathrm{m}$ in diameter. However, in most cases, the parenchymal cells are damaged, which has resulted in irregular shaped elements that are difficult to distinguish individually (Figs. 2d, 3a, 4a, g, h). Although resin canals are poorly preserved, they have been observed in a few longitudinally sectioned leaves within the spongy mesophyll (Fig. 4g, h). Resin canals are distinguished as incomplete longitudinal lacunae up to $70 \mu \mathrm{m}$ wide, whereas epithelial cells are preserved in patches. Each of these cells is rectangular-elongate, reaching $26.5 \mu \mathrm{m}$ long and $7.3 \mu \mathrm{m}$ wide (Fig. 4h).

A vascular bundle in longitudinal view is recognized in the mesophyll of the largest leaf, showing a somewhat rectilinear trajectory (Figs. 2c, 4a). The bundle appears collateral with the xylem composed of tight files of up to 9 tracheids approximately $3.8 \mu \mathrm{m}$ wide, each showing helical wall thickenings (Fig. 4a). Contiguous to the most adaxially placed tracheids, patches of several transfusion tracheids are recognized. They are almost quadrangular in shape, are approximately 29.7 long and $25 \mu \mathrm{m}$ wide and have poorly preserved areolate pits; in any case, characteristic reticulate wall thickening has been identified (Fig. 4b). Phloem cells have not been recognized due to poor preservation. Two damaged vascular bundles, $26 \mu \mathrm{m}$ in diameter in transverse view, are observed in apical sections of leaves that are transversally and obliquely oriented (Fig. 4d). Within the bundle, only xylem tracheids are recognized, as all other individual vascular cells are too difficult to discern (Fig. 4d). Xylem tracheids appear in two groups of very small quadrangular cells that have thick walls and empty lumens and look quite distinct from the surrounding foliar tissues (Fig. 4d). Of note in these apical sections is a well-developed palisade mesophyll, as the epidermal cells and hypodermal fibers exhibit poor preservation (Fig. 4d).

Some of the leaves were found in close association with young conifer-like stems that have been preserved in longitudinal-tangential and longitudinal-radial views (Fig. 2a-b). Their lengths and widths are incomplete and reach up to $20 \mathrm{~mm}$ long and to $9 \mathrm{~mm}$ wide. In radial view, the rays are homocellular and composed of approximately quadrangular cells $21 \mu \mathrm{m}$ long and $11 \mu \mathrm{m}$ wide (Fig. 5a). Tangential ray walls appear straight. The latter and the horizontal walls are unpitted. The arrangement of the pits on tracheid radial walls is uniseriate. Pits are contiguous with neighboring pits, are circular in outline reaching $9.4 \mu \mathrm{m}$ in diameter and have circular inner aperture $2.5 \mu \mathrm{m}$ in diameter. Cross-fields possess five contiguous alternate bordered pits; however, the exact number is difficult to determine due to poor preservation (Fig. 5c). In tangential view, the rays are exclusively uniseriate and range from 1-6 cells, with the most common being 1-2 cells high. The transverse and tangential walls of the parenchymal cells are smooth. These cells are barrel-shaped, reaching 19 $\mu \mathrm{m}$ high and $10 \mu \mathrm{m}$ wide. No pits are observed in tracheid tangential walls (Fig. 5e). 

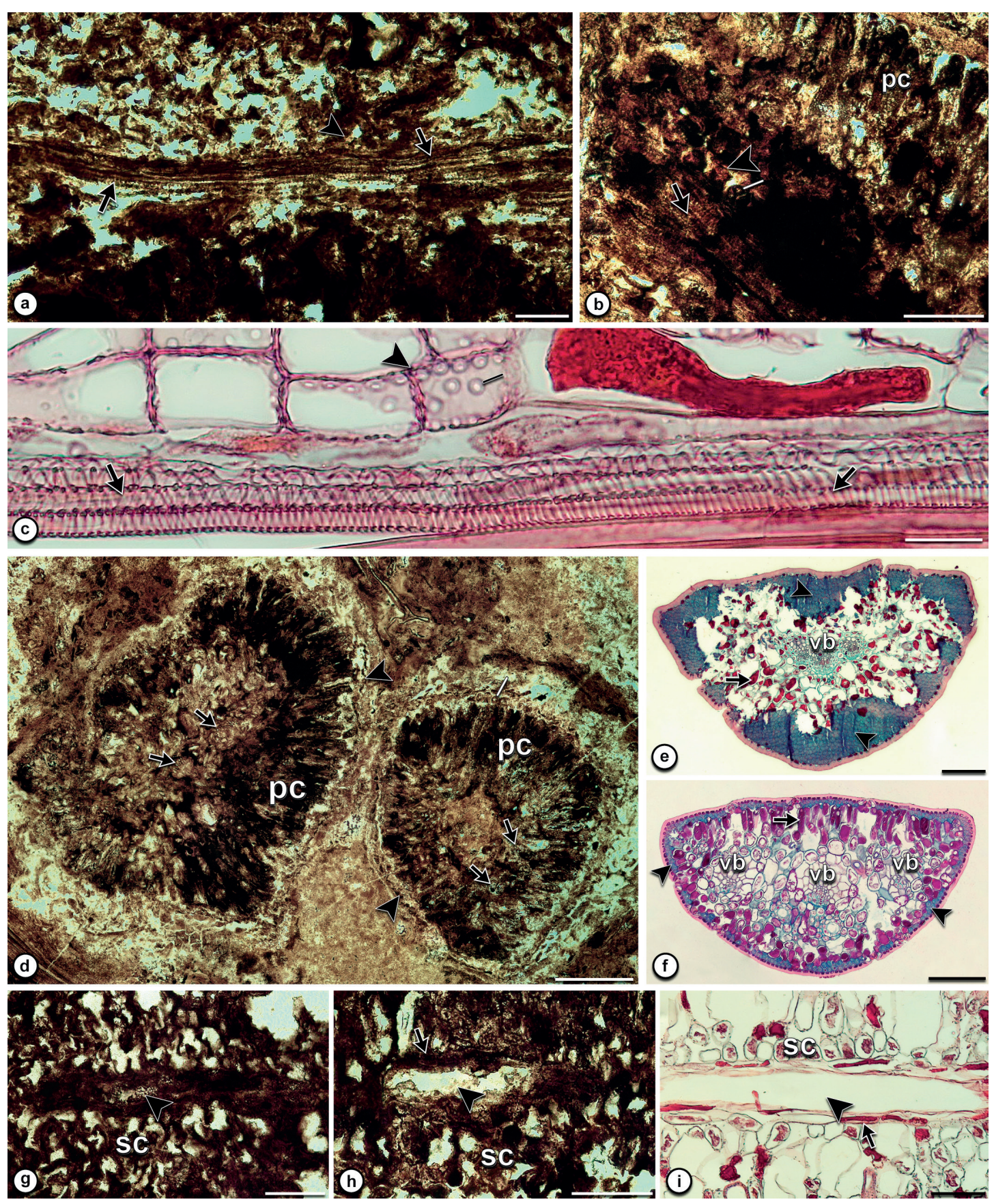

Figure 4 - Permineralized conifer-like leaf and comparative leaf of extant Araucaria. (a, b, d, g, h. f) Fossil leaf. (c, e, f, i) Extant leaf. (e) A. araucana. (f, i) A. bidwillii. (a-c) Details of vascular bundle in longitudinal view showing tracheids with helical wall thickenings (arrows), transfusion tracheids (arrow heads) and pits (bars). Note palisade parenchyma cells (pc). (a-b) Transfusion tracheids poorly preserved in patches. Bar scales: $\mathbf{a}=50 \mu \mathrm{m}, \mathbf{b}=100 \mu \mathrm{m}$, $\mathbf{c}=25 \mu \mathrm{m}$. (d-f) Apical part of leaves. (d) Oblique-transverse section. Arrows show two vascular bundles poorly preserved and arrows head probable hypodermal fibers. Note few hypodermal fibers in transverse section (bar) and palisade parenchyma cells (pc). Bar scale $=250 \mu \mathrm{m}$. (e-f) Transverse section. Note three vascular bundles (vb), one incipient. Arrows indicate palisade parenchyma cells and arrow heads hypodermal fibers. Bar scales $=200 \mu \mathrm{m}$. (g-i) Resin canal in longitudinal view (arrow heads). Arrows show epithelial cells. Note spongy parenchyma cells (sc). Bar scales $=100 \mu \mathrm{m}$. 

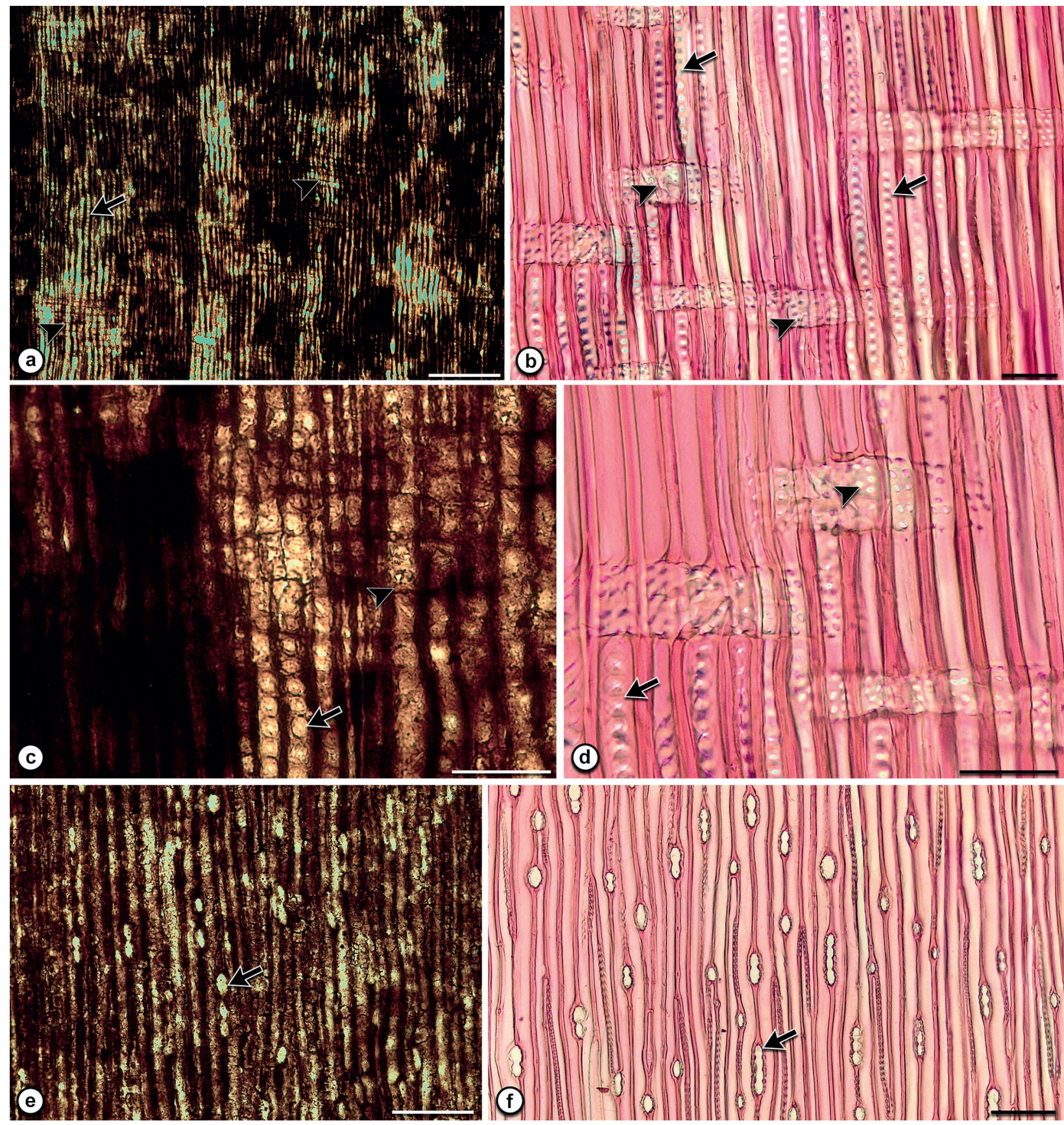

Figure 5 - Permineralized conifer-like stem and comparative stem of extant Araucaria angustifolia. (a, c, e) Fossil stem. (b, d, f) Extant stem. (a-d) Radial section. Tracheids with uniseriate contiguous pits (arrows) and cross-fields with numerous contiguous alternate pits (arrow heads). Bar scales: $\mathbf{a}=200 \mu \mathrm{m}, \mathbf{b}-\mathbf{d}=50 \mu \mathrm{m}$. e, f. Tangential section. Note uniseriate rays (arrows). Bar scales $=100 \mu \mathrm{m}$. 


\section{DISCUSSION}

\section{BOTANICAL AFFINITY AND GENERAL REMARKS}

The permineralized foliar structures described herein correspond to sterile foliage that shows general anatomical features characterizing most conifer-like leaves. This has been revealed by the presence of an epidermis with thick-walled cells, a hypodermis composed of several (3-4) fiber layers, resin canals and transfusion tracheids associated with the vascular bundle (Chamberlain 1935, Evert 2006).

Taking into consideration other organs of foliar origin, such as cataphylls and bracts, it appears that they show quite distinct anatomical features to those observed in the fossils from the $\mathrm{La}$ Matilde Formation. In no case does the Patagonian foliage exhibit a mesophyll of undifferentiated parenchymal cells with few sclerenchymal cells and a poorly developed xylem that characterizes the cataphylls or bud scales of most conifers (Romberger 1963), such as Pinaceae (Sacher 1955) or Podocarpaceae (Del Fueyo 1988), among others. In addition, the specimens' leaf anatomy from the La Matilde Formation does not even show any tissue comparable to those observed in coniferous bracts, where the ground tissue is notably undifferentiated. It is mainly parenchymatous with scattered sclereids such as in the bracts of the Cretaceous Araucaria nipponensis from Japan and Russia (Stockey et al. 1994) or it is merely sclerotic similar to the bracts of the Jurassic Araucaria mirabilis from Patagonia (Stockey 1978). In other cases, the bract ground tissue is only composed of few parenchymal cells that are full of a dark material, similar to the Jurassic Cheirolepidiaceae Pararaucaria from Patagonia (Escapa et al. 2012, 2013). Furthermore, bracts in extant conifers follow a similar anatomical organization, as most cases essentially formed from parenchymal cells filled with resin-like or tanninlike material and sclereids, as observed in Abies grandis of the Pinaceae and in several taxa of the
Cupressaceae (Singh and Owens 1982, Takaso and Tomlinson 1989, Farjon 2005), among others.

Within Coniferales, leaves are usually needlelike with a middle vein or two bundles, such as those present in Pinaceae and in the remarkable Sciadopityaceae, which have two needles fused together along the posterior margin, or scalelike and single-veined as in Cupressaceae and in some Cheirolepidiaceae, Podocarpaceae and Araucariaceae. However, many other conifers have linear-lanceolate, small (most belonging to Taxaceae) or large (Palissyaceae, Cephalotaxus, and some Podocarpaceae) leaves with one vascular bundle, whereas other conifers have large, broad, multi-veined leaves similar to those observed in most Araucariaceae and in Nageia of the Podocarpaceae (De Laubenfelds 1953, Krüssmann 1985, Farjon 2008, Ghimire et al. 2014).

According to this, and despite the fact that the general morphology of the Patagonian leaves is difficult to discern, it is possible to infer it, at least partially, by considering the size and shape of the blade sections and the arrangement of the several foliar tissues (Fig. 6a, b, f, h). Because the largest longitudinal foliar section is $6.3 \mathrm{~mm}$ long, 0.8 $\mathrm{mm}$ thick and shows a well-developed mesophyll (Fig. 6h), it is suggested that the Patagonian leaves would have been of large size and with a kind of broad shape rather than of small size and slender form. Although the overall foliar length cannot be determined, such a long and large longitudinal section with almost straight parallel foliar surfaces is indicative of somewhat linear-lanceolate rather than scale-like or needle-like leaves. Because this longitudinal section is almost oblong in outline and, considering that neither an apical blade nor basal blade parts are preserved, it is suggested that the section most likely corresponds to a portion between the middle and the margin of the blade (Fig. 6h). However, it is possible that the longitudinal sections that are $2.7 \mathrm{~mm}$ long and $0.9 \mathrm{~mm}$ thick and do not show a vascular bundle but mainly 
palisade and spongy tissues, would have been located close to the blade margin (Fig. 6f). Because a conspicuous vascular bundle in longitudinal view (Fig. 6h) and two damaged vascular bundles in the small cross-oblique sections (Figs. 4d, 6b) can be seen in the Patagonian leaves, it is proposed that the leaves were most likely multi-veined rather than univeined. That the Patagonian leaves described here are not considered two-veined is based primarily on the fact that there is neither a fossil nor extant conifer that is known to have large, broad leaves with only two bundles; they are always multi-veined (Chamberlain 1935, Axsmith et al. 1998). Furthermore, in the Patagonian leaves, the foliar apical portions that show a semi-circular outline (Fig. 4d) are indicative of terete leaf apices.

This evidence reveals that the foliage from the La Matilde Formation would have been perhaps composed of large, broad, multi-veined, linearlanceolate leaves that became terete towards the apex (Fig. 6a) showing an isobilateral, welldeveloped mesophyll, resin canals, unistratified epidermis with stomata on both surfaces, a hypodermis composed of one to four fiber layers, collateral vascular bundles with xylem composed of helical thickening walled tracheids and adaxially contiguous transfusion tracheids.

\section{COMPARISON AMONG CONIFER LEAVES}

Because the morphological and anatomical data suggest an affinity of the La Matilde Formation foliage to conifers with large, broad and multiveined leaves, the comparisons will be focused on fossil and extant coniferous taxa that have similar foliar characteristics and whose anatomy have been preserved or studied in detail.

\section{Comparison with fossil broad multi-veined conifer} leaves

Remains of large, broad multi-veined conifer leaves are common in the Mesozoic worldwide, among which foliar impressions or compressions with preserved cuticle are remarkably abundant. There are Cretaceous records of the Araucariaceae with several species of Araucaria from Patagonia ( $A$. grandifolia), Antarctica (A. fibrosa), New Zealand (A. haastii), Alabama (A. bladenensis) and Australia (A. seorsum, A. lanceolatus, A. acutifoliatus), as well as Agathis victoriensis from Australia (Bose 1975, Cantrill 1992, Césari et al. 2001, 2009, Del Fueyo and Archangelsky 2002, Stults et al. 2012), among others. Additionally, within the Podocarpaceae, the multi-veined leaves of Podocarpus (Nageia) sujfunensis and Podocarpus (Nageia) ryosekiensis were described from the Lower Cretaceous of Russia and Japan, respectively (Krassilov 1974, Kimura et al. 1988). Furthermore, numerous multiveined conifer taxa of unknown family have been found, such as Desmiophyllum from the Upper Triassic of China (Zhou 1983), Heidiphyllum from the Triassic of the Southern Hemisphere (Axsmith et al. 1998), Podozamites from the Late Triassic of Greenland (Harris 1935) and the Cretaceous of Australia (Cantrill 1990), Antarctica (Falcon Lang et al. 2001) and Brazil (Kunzmann et al. 2004), and Lindlecladus from the Cretaceous of Brazil (Kunzmann et al. 2004).

In contrast, Mesozoic permineralized multiveined conifer leaves that show internal preservation are limited to those foliar remains described from Antarctica, Australia and Japan, which exhibit certain anatomical features not observed in the Patagonian leaves. The exceptionally preserved multi-veined leaves of Notophytum krauselii, a Podocarpaceae from the Middle Triassic of Antarctica, differ markedly in that they show no hypodermal cells but do have a dorsiventral mesophyll differentiated into adaxial palisade tissue and densely packed spongy tissue, as well as accessory transfusion tissue oriented almost obliquely to the vascular bundles (Axsmith et al. 1998). Moreover, the multi-veined leaves attached to the araucarian ovulate cone axis of Emwadea 


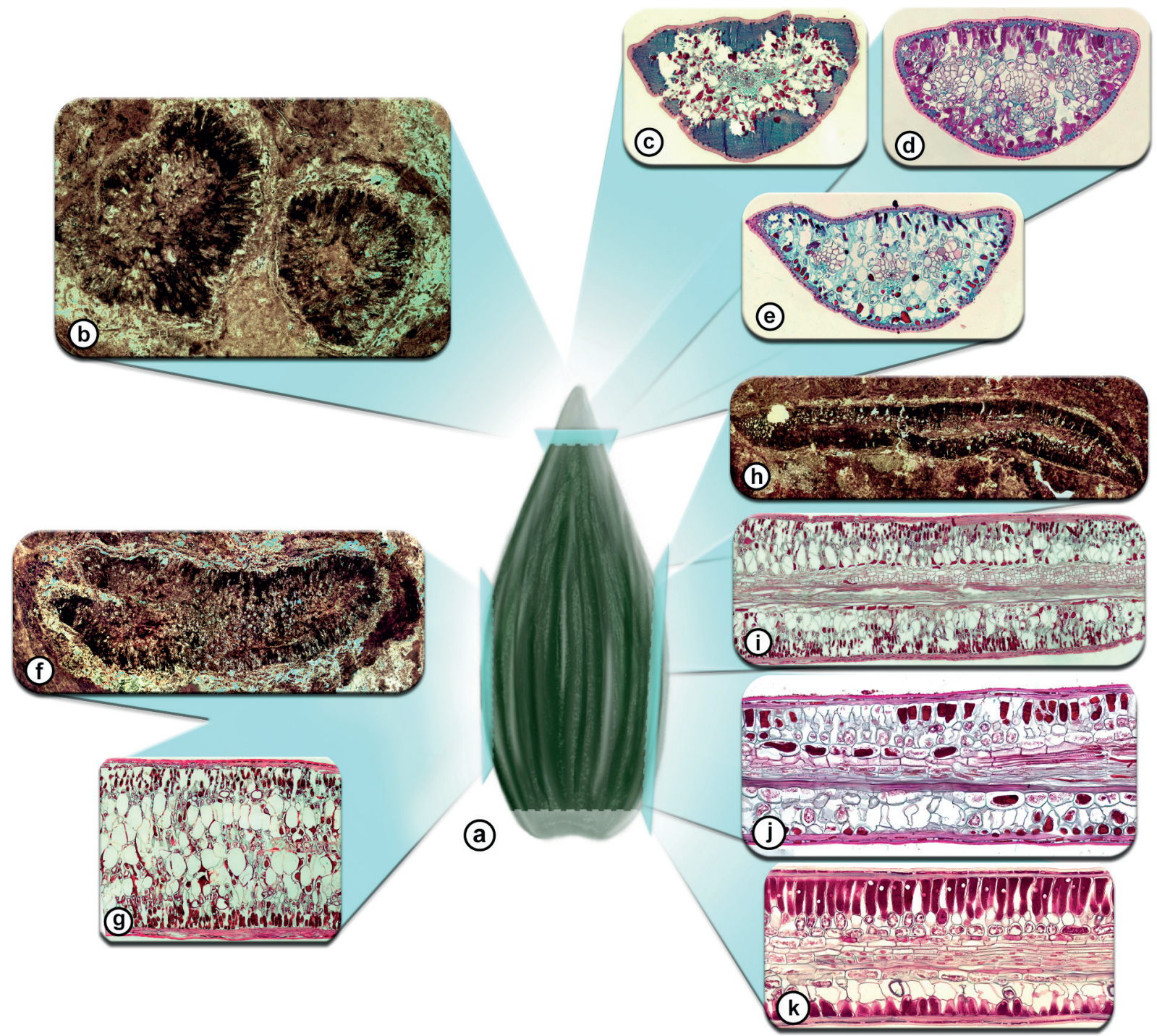

Figure 6 - Hypothetical reconstruction of the conifer-like leaves from La Matilde Formation and its comparison with extant Araucaria leaves. (a) Hypothesized fossil leaf showing general morphology. Large, broad linear-lanceolate and multiveined leaf. Apex and base unknown. (b, f, h) Fossil leaves. (b) Transverse-oblique view near the apex. (f, h) Longitudinal view. (f) Margin of the leaf showing no vascular bundle. (h) Most inner leaf part showing one vascular bundle. (c-e, g, i-k) Leaf of extant Araucaria spp. (c, g, i) A. araucana, (d, k) A. bidwillii, (e, j) A. angustifolia. (c-e) Transverse views. (g-k) Longitudinal views. (g) Section showing no vascular bundle. (i-k) Sections through one vascular bundle.

microcarpa from the late Albian of Australia are distinct because the stomata are confined to the adaxial epidermis, and the mesophyll is dorsiventral, poorly developed and has large mucilage cells (Dettmann et al. 2012).

Ohana and Kimura (1993) described multiveined leaves that were quite well preserved belonging to Brachyphyllum vulgare from the Coniacian-Santonian of Japan, which are supposed to be identical to the leaves found associated with the cone axis of Araucaria vulgaris, which are assigned to section Yezonia of Araucaria by Ohsawa et al. (1995). Leaves of the Patagonian specimens are distinguished from those of $B$. vulgare because they are hypostomatic with a dorsiventral mesophyll in which numerous and large resin channels are present below the vascular bundles. 
Comparison with extant broad multi-veined conifer leaves

As noted, four extant conifers, Nageia of the Podocarpaceae, Agathis, most Araucaria species and Wollemia of the Araucariaceae, have large, broad and multi-veined leaves that share some anatomically similar characteristics but differ in others from those of the La Matilde Formation.

According to several authors, Nageia species are either amphistomatic or hypostomatic (Buchholz and Gray 1948, Woltz et al. 1987, Jin et al. 2010). In particular, leaves of Nageia motleyi and $N$. wallichiana are amphistomatic with an isobilateral mesophyll similar to that observed in the Patagonian specimens (Orr 1944, Woltz et al. 1987). The transfusion tissue in Nageia is reduced to a few tracheids flanking each bundle (Orr 1944), while in the Patagonian leaves they are found above the xylem. In addition, accessory transfusion tissue, which is a typical podocarpoid feature, is lacking in the Patagonian leaves similar to those of the Nageia species (Woltz et al 1987, Hu and Yao 1981). However, within Nageia, the presence of resin canals beneath each of the many vascular bundles is a distinct characteristic that it does not share with the Patagonian specimens.

Among the three araucarian taxa, leaves of the La Matilde Formation differ significantly from those of Agathis species in that the latter are mostly hypostomatic and the mesophyll is markedly dorsiventral in which large, branched and thickwalled sclereids are randomly arranged (Seward and Ford 1906, Kausik 1976, Stockey and Atkinson 1993).

Conversely, leaves of the monospecific Wollemia nobilis are amphistomatic as observed in the Patagonian specimens. However, the former are distinguished by having a dorsiventral mesophyll with singly large sclereids and enlarged mucilage cells in the spongy tissue (Chambers et al. 1998, Burrows and Bullock 1999). These unusual mucilage cells are confined to Wollemia and Araucaria (Bamber et al. 1978, Burrows and Bullock 1999, Mastroberti and Mariath 2003, 2008). The Patagonian leaves appear to lack these mucilage cells, but this could be due to preservational factors.

Within the four recognized sections of Araucaria (Wilde and Eames 1952), it is considered here that those species belonging to the Araucaria, Bunya and Intermedia sections with large, multi-veined leaves because those of the Eutacta section have reduced and mostly univeined leaves. Stockey and Ko (1986) pointed out that all species of Araucaria are amphistomatic (Figs. 3b, d, 6i-k), which are similar to the Patagonian leaves. However, Araucaria differs from the latter by having large sclereids and the so-called mucilage cells in the mesophyll. Furthermore, some species of Araucaria have a dorsiventral mesophyll, whereas others, such as the two South American species, A. angustifolia and A. araucana, which both belong to section Araucaria, and A. bidwillii of section Bunya, exhibit an isobilateral mesophyll (Fig. 6i-k) similar to that of the Patagonian leaves (Seward and Ford 1906, Mastroberti and Mariath 2003). In this regard, the well-developed and densely packed adaxial and abaxial palisade cells of the Patagonian specimens are most similar to those exhibited by A. araucana (Figs. 3b, d, g, 6g, i) rather than those shown by $A$. angustifolia and $A$. bidwillii where they are more developed adaxially than abaxially (Fig. 6j, k).

However, the Patagonian foliar apical tissues observed in the transverse sections more closely resemble those seen in $A$. angustifolia and $A$. bidwillii, where there is a well-developed palisade mesophyll with two vascular bundles (Figs. 4f, 6d, e). In contrast, the layers of hypodermal fibers are anatomical features that the Patagonian foliar apex share with that of A. araucana leaves (Figs. 4e, 6c).

Because the largest Patagonian specimen is preserved in a longitudinal section along a vascular 
bundle, it is not possible to confirm whether the leaves have resin canals alternating with vascular bundles, as is the case for Agathis, Araucaria (Figs. 4e, f, i, 6c-e) and Wollemia (Seward and Ford 1906, Bamber et al. 1978, Burrows and Bullock 1999). Moreover, this is also the reason why it is not possible to discern a precise arrangement of transfusion tissue in the Patagonian leaves. Even though the tissue in the Patagonian leaves is poorly preserved above the xylem, its arrangement partially resembles that of the three araucarian genera due to a characteristic inverted, U-shaped arc enclosing each vascular bundle (Fig. 4c) (Kausik and Bhattacharya 1977, Hu and Yao 1981, Mastroberti and Mariath 2003).

The conifer leaves from the La Matilde Formation appear to have a closer affinity to the large, broad and multi-veined leaves of the living Araucariaceae rather than those of Nageia of the Podocarpaceae or the permineralized ones from Antarctica, Australia and Japan. The Patagonian leaves exhibit anatomical features that more closely resemble those present in the genus Araucaria, such as the presence of stomata in both epidermises, an isobilateral mesophyll, densely packed palisade cells and transfusion tissue above the xylem. However, some key anatomical features are not preserved in the Patagonian specimens such as the precise position of resin canals, the presence of mucilage cells or the arrangement of transfusion tissue, which make it difficult to assign a relationship to some living species of Araucaria.

Additionally, the anatomy of associated conifer-like stems (Fig. 5a, c, e) shows wood characters of unquestionable araucarian affinity (Philippe 1993, 1995, Philippe and Bamford 2008), such as contiguous bordered pits on the radial walls of tracheids, uniseriate rays and cross-fields with numerous, contiguous alternate bordered pits (Fig. $5 b, d, f)$.
PALAEONVIRONMENT AT BARDA BLANCA LOCALITY

According to Mazzoni et al. (1981) and De Barrio et al. (1999) the sediments of the La Matilde Formation at Barda Blanca locality exhibit a continental sequence, characteristic of a low energy fluvial environment. These authors have also indicated that the presence of laminated pelitic deposits associated with carbonaceous levels may indicate the occurrence of several water bodies (shallow lagoons or swamps) in the flood plains, which in part exhibited marshy conditions (lentic and reducing). Simultaneous, with the La Matilde deposition, intense volcanism developed in more remote areas, whose pyroclastic products were deposited by ash and volcanic dust in the same sediment basin (Panza and Irigoyen 1995). In addition, the sedimentological data allowed Mazzoni et al. (1981) to point out that the La Matilde Formation was deposited in a humid and warm paleoclimate. These environmental conditions are supported by the diverse biota found within the La Matilde Formation sediments, including ferns (Herbst 2003), Equisetaceae (Falaschi et al. 2009), anurans (Baéz and Nicoli 2004) and gymnosperm woods with marked growth rings (Gnaedinger 2007a), among others. In general, this is in accordance with the Jurassic paleoclimate data provided by Volkheimer (1969) and Volkheimer et al. (2008) who have suggested that climatic changes for the La Matilde Formation would have occurred during its deposition, from a short period of sub-humid, then semi-arid and finally arid conditions during the Middle-Upper Jurassic.

Because plants are quite sensitive to environmental conditions, they most often respond by developing foliar anatomical features that are adapted according to whether the habitat they grow in is xeric, mesic or hydric (Pyykkö 1966, Fahn and Cutler 1992). Particularly, the permineralized leaves from the La Matilde Formation show thick- 
walled epidermal cells, a well-marked palisade parenchyma on both surfaces and well-developed mechanical tissue composed of hypodermal cells one to four layers deep. Furthermore, these foliar characteristics are recognized as xeromorphic anatomical features, which are developed by plants, so-called xerophytes that inhabit either a dry climate or a dry or low-nutrient substrate (Fahn and Cutler 1992). Accordingly, leaves from the La Matilde Formation agree with the generally accepted concept that the anatomy of the conifer leaf is in most cases xeromorphic (Chamberlain 1935, Ghimire et al. 2014, among others).

The presence of thick-walled epidermal cells and hypodermal layers in the Patagonian leaves may indicate that the parent plants probably lived in a dry, sunny habitat and that the development of such features would have offered the cells protection against the effects of excessive light or against the mechanical action of the wind, as well as prevent the collapse of vital chlorenchyma. These particular foliar adaptations are also observed in extant plants that grow in xeric conditions (Pyykkö 1966, Burrows 2001). However, Fahn and Cutler (1992) have pointed out that similar characters are also exhibited in plants adapted to cold winter desiccation, such as in the conifer Pseudotsuga menziesii.

Pyykkö (1966) and Burrows (2001) have found that most living xeromorphic species inhabiting areas with ample light either in East Patagonia or in New South Wales, exhibit an isobilateral mesophyll distribution with well-developed palisade tissue. Additionally, Pyykkö (1966) has proven that longer palisade parenchymal cells occur in plants that grow in habitats with sufficient water availability, whereas palisade cells become shorter in comparatively drier habitats. Accordingly, leaves with markeddeveloped palisade tissue evaporate more water per unit area of the epidermis than those that have a less developed and less compact palisade parenchyma (Pyykkö 1966). Because the Patagonian fossil leaves are isobilateral with well-developed palisade tissue exhibiting long and compact parenchymal cells, it may suggest that the environmental conditions of the parent plant's habitat during the deposition of the La Matilde Formation was most likely exposed to a high light intensity and an adequate quantity of water in the soil.

Burrows (2001) has found in 39 xeromorphic species from Australia a strong correlation between isobilateral mesophyll distribution and an amphistomatous condition, as was observed in the Patagonian fossil leaves. On the other hand, Parkhurst (1978) has pointed out that thick leaves are likely to be amphistomatous, and this relation has also been found in the Patagonian fossil specimens, considering that these leaves are 800 $\mu \mathrm{m}$ thick. Amphistomatous leaves are considered better adapted to increasing maximum leaf conductance of $\mathrm{CO}_{2}$ than hypostomatous leaves (Mott et al. 1982). These authors have suggested that plants with high photosynthetic capacity have an advantage when growing in regions with high solar radiation and rapid fluctuations in available soil water. Accordingly, due to the foliar thickness and the amphistomatous conditions shown by the fossil leaves, it is suggested here that the parent plants would have been most likely adapted to an environment with high light intensity and sufficient water availability, allowing for a maximum photosynthetic $\mathrm{CO}_{2}$ uptake.

\section{CONCLUSIONS}

The fossil material described herein represents the first anatomically preserved conifer-like leaves to be characterized from the Middle Jurassic La Matilde Formation in southern Patagonia. Leaves are assigned to conifers based on the following foliar features: thick-walled epidermal cells, a sclerenchymatic hypodermis, a mesophyll differentiated into palisade and spongy tissues, resin canals and transfusion tracheids associated with 
the vascular bundle. The assignment to conifers is reinforced by the close association of the single leaves with young, conifer-like stems.

Anatomically, all of the permineralized leaves show identical foliar characters and, thus, suggest that they were all likely produced by the same parent plant. Additionally, the occurrence of welldeveloped palisade tissue and hypodermal fiber layers in all specimens suggest that all of the leaves were mature at the time of fossilization.

Based on the size and shape of the blade sections and the disposition of the foliar tissues exhibited by the permineralized Patagonian foliage, it is presumed that the morphology of the leaves was most likely large, broad and linear-lanceolate. Additionally, the preserved foliar anatomical features show that the leaves were amphistomatic with an isobilateral and well-developed mesophyll, possessed resin canals with rectangular-elongate epithelial cells, an unistratified epidermis, a hypodermis formed by 1 to 4 fiber layers, were multi-veined with collateral vascular bundles, and had helical thickening walled xylem tracheids and adaxially contiguous transfusion tracheids.

Although the Patagonian fossil leaves are more closely resemble conifers, it is difficult to assign them to any known family due to the poor preservation of some key foliar tissues. Among conifers with large, broad and multi-veined leaves, the foliar anatomical features of the specimens from the La Matilde Formation show a certain affinity to those of the Araucariaceae, especially those exhibited by the species of the Araucaria sections, Araucaria and Bunya. These features include the occurrence of stomata in both surfaces of the epidermis, an isobilateral mesophyll, densely packed palisade cells and transfusion tissue above the xylem. In the fossil leaves, it was not possible, due to the preservation, to determine the exact arrangement of transfusion tissue, the position of resin canals and the presence of mucilage cells. Therefore, the Patagonian leaves cannot be placed in any known living species of Araucaria. However, the anatomical features observed in the fossil leaves are perhaps most similar to extant $A$. araucana, which is an endemic taxon of southern Patagonia.

As is the case for most conifer leaves, the Patagonian fossil specimens show xeromorphic foliar anatomical features, which include thickwalled epidermal cells and well-developed palisade and mechanical tissues. Furthermore, the occurrence in the permineralized leaves of an isobilateral mesophyll and stomata distributed along both foliar surfaces may suggest that during the deposition of the La Matilde Formation, the parent plant was well adapted to the environmental conditions, which most likely included a high light intensity and an adequate quantity of water in the soil, increasing the maximum leaf conductance of $\mathrm{CO}_{2}$.

\section{ACKNOWLEDGMENTS}

This study is dedicated to the late Prof. Rafael Herbst for his many contributions to the Mesozoic floras of Patagonia. We thank Orlando Cárdenas for technical assistance in re-mounting several peels. The authors are grateful to the Editor-in-Chief Alexander W. A. Kellner, the Associate Editor and two anonymous reviewers for all their valuable suggestions that have improved the manuscript. We are grateful to Gabriela Zarlavsky for sectioning leaves and young stems of extant Araucaria spp. This article was supported by funds ANPCyT PICT 2012/528, CONICET PIP 112-20120100212 granted to GMDF; SGCyT-UNNE.PI 20152018, Q005-2014, CONICET PIP 2014-2016, 112 20130100317 granted to SCG and ANPCyT PICT 2015/2206 granted to MAC.

\section{AUTHOR CONTRIBUTIONS}

All the authors participated equally in the design and carrying out the research and in the writing of the manuscript. 


\section{REFERENCES}

AXSMITH BJ, TAYLOR TN AND TAYLOR EL. 1998. Anatomically preserved leaves of the conifer Notophytum krauselii (Podocarpaceae) from the Triassic of Antarctica. Amer J Bot 85: 704-713.

BÁEZ AM AND NICOLI L. 2004. A new look at an old frog: the Jurassic Notobatrachus Reig from Patagonia. Ameghiniana 41: 257-270.

BAMBER RK, SUMMERVILLE R AND GREGORY J. 1978. Unusual cells in the mesophyll zone of the leaves of Araucaria. Austral J Bot 26: 177-187.

BERTELS A. 1977. Estratigrafía y micropaleontología de la Formación San Julián en su área tipo, provincia de Santa Cruz. Ameghiniana 14: 233-293.

BOSE MN. 1975. Araucaria haastii Ettingshausen from Shag Point, New Zealand. Palaeobotanist 22: 76-80.

BUCHHOLZ JT AND GRAY NE. 1948. A taxonomic revision of Podocarpus. I. The sections of the genus and their subdivisions with special reference to leaf anatomy. J Arnold Arbor 29: 49-63.

BURROWS GE. 2001. Comparative anatomy of the photosynthetic organs of 39 xeromorphic species from subhumid New South Wales, Australia. Int J Plant Sci 162: 411-430.

BURROWS GE AND BULLOCK S. 1999. Leaf anatomy of Wollemi pine (Wollemia nobilis, Araucariaceae). Austral J Bot 47: 795-806.

CALDER MG. 1953. A coniferous petrified forest in Patagonia. Bull Brit Mus (Nat Hist), Geol 2: 97-137.

CANTRILL DJ. 1990. Broad leafed coniferous foliage from the Lower Cretaceous Otway Group. Southeastern Australia. Alcheringa 15: 177-190.

CANTRILL DJ. 1992. Araucarian foliage from the Lower Cretaceous of southern Victoria, Australia. Int J Plant Sci 153: 622-645.

CÉSARI S, MARENSSI SA AND SANTILLANA SN. 2001. Conifers from the Upper Cretaceous of Cape Lamb, Vega Island, Antarctica. Cret Res 22: 309-319.

CÉSARI S, MARENSSI SA AND SANTILLANA SN. 2009. Araucaria fibrosa, a new name to replace the illegitimate name Araucaria antarctica Césari, Marenssi and Santillana, 2001. Cret Res 30: 1169.

CHAMBERLAIN CJ. 1935. Gymnosperms. Structures and evolution. Chicago: Chicago University Press, 484 p.

CHAMBERS TC, DRINNAN AN AND MCLOUGHLIN S. 1998. Some morphological features of Wollemi pine (Wollemia nobilis: Araucariaceae) and their comparison to Cretaceous plant fossils. Int J Plant Sci 159: 160-171.

CHANNING A, ZAMUNER AB AND ZÚÑIGA A. 2007. A new Middle-Late Jurassic flora and hot spring chert deposit from the Deseado Massif, Santa Cruz province, Argentina. Geol Mag 144: 401-411.
CHRISTENHUSZ MJM, REVEAL JL, FARJON A, GARDNER MF, MILL RR AND CHASE MW. 2011. A new classification and linear sequence of extant gymnosperms. Phytotaxa 19: 55-70.

CRONQUIST A, TAKHTAJAN A AND ZIMMERMANN W. 1966. On the higher taxa of Embryobionta. Taxon 14: 129134.

DE BARRIO RE. 1993. El vulcanismo ácido Jurásico en el Noroeste de Santa Cruz, Argentina. In: Actas 4 del $12^{\circ}$ Congreso Geológico Argentino, Mendoza, Argentina, p. 189-198.

DE BARRIO RE, PANZA JL AND NULLO FE. 1999. Jurásico y Cretácico del Macizo del Deseado, provincia de Santa Cruz. In: Caminos R (Ed), Geología Argentina, vol. 29, Anales del Instituto de Geología y Recursos Minerales, Buenos Aires: Servicio Geológico Minero Argentino, p. 511-527.

DE GIUSTO JM. 1955. Informe geológico preliminar, zona San Julián. Informe Yacimientos Petrolíferos Fiscales, Buenos Aires, 15 p. (Unpublished).

DE GIUSTO JM, DI PERSIA CA AND PEZZI E. 1980. Nesocratón del Deseado. In: Leanza AF (Ed), Actas 2 del $2^{\circ}$ Simposio de Geología Regional Argentina, Academia Nacional de Ciencias, Córdoba, Argentina, p. 1389-1430.

DE LAUBENFELDS DJ. 1953. External morphology of coniferous leaves. Phytomorphology 3: 1-20.

DEL FUEYO GM. 1988. Anatomía y ontogenia foliar de Podocarpus parlatorei (Podocarpaceae). Bol Soc Arg Bot 25: 353-367.

DEL FUEYO GM AND ARCHANGELSKY A. 2002. Araucaria grandifolia Feruglio from the Lower Cretaceous of Patagonia, Argentina. Cret Res 23: 265-277.

DETTMANN ME, CLIFFORD HT AND PETERS M. 2012. Emwadea microcarpa gen. et sp. nov. anatomically preserved araucarian seed cones from the Winton Formation (late Albian), western Queensland, Australia. Alcheringa 36: 217-237.

ECHEVESTE H, FERNÁNDEZ R, BELLIENI G, TESSONE M, LLAMBÍAS E, SCHALAMUK I, PICCIRILLO E AND DE MIN A. 2001. Relaciones entre las Formaciones Bajo Pobre y Chon Aike (Jurásico Medio a Superior) en el área Estancia El Fénix-Cerro Huemul, zona centrooccidental del Macizo del Deseado, provincia de Santa Cruz. Rev Asoc Geol Arg 56: 548-558.

ESCAPA IH, CÚNEO RN, ROTHWELL GW AND STOCKEY RA. 2013. Pararaucaria delfueyoi sp. nov. from the Late Jurassic Cañadón Calcáreo Formation, Chubut, Argentina: Insights into the evolution of the Cheirolepidiaceae. Int $\mathrm{J}$ Plant Sci 174: 458-470.

ESCAPA IH, ROTHWELL GW, STOCKEY RAAND CÚNEO RN. 2012. Seed cone anatomy of Cheirolepidiaceae (Coniferales): Reinterpreting Pararaucaria patagonica Wieland. Amer J Bot 99: 1058-1068.

EVERT RF. 2006. Esau's Plant Anatomy: Meristems, Cells, and Tissues of the Plant Body. Their Structure, Function, and Development. New Jersey: Wiley-Interscience, 601 p. 
FAHN A AND CUTLER DF. 1992. Xerophytes. Berlin: Borntraeger, $176 \mathrm{p}$.

FALASCHI P, GROSFELD J, ZAMUNER AB, FOIX N AND RIVERA SM. 2011. Growth architecture and silhouette of Jurassic conifers from La Matilde Formation, Patagonia, Argentina. Palaeogeog Palaeoclimatol Palaeoecol 302: 122-141.

FALASCHI P, ZAMUNER AB AND FOIX N. 2009. Una nueva Equisetaceae fértil de la Formación La Matilde, Jurásico Medio, Argentina. Ameghiniana 46: 263-272.

FALCON LANG HJ, CANTRILL DJ AND NICHOLS GJ. 2001. Biodiversity and terrestrial ecology of a midCretaceous, high-latitude floodplain, Alexander Island, Antarctica. J Geol Soc 158: 709-724.

FARJON A. 2005. A Monograph of Cupressaceae and Sciadopitys. Surrey: Royal Botanic Gardens, 648 p.

FARJON A. 2008. A Natural History of Conifers. Portland: Timber Press, 304 p.

GALLEGO OF. 1994. Conchostracos Jurásicos de Santa Cruz y Chubut, Argentina. Ameghiniana 31: 333-345.

GALTIER J AND PHILLIPS TL. 1999. The acetate peel technique. In: Jones TP and Rowe NP (Eds), Fossil Plants and Spores: modern techniques. London: Geological Society, p. 67-70.

GARCÍA MASSINI J, ESCAPA IH, GUIDO DM AND CHANNING A. 2016. First glimpse of the silicified hot spring biota from a new Jurassic chert deposit in the Deseado Massif, Patagonia, Argentina. Ameghiniana 53: 205-230.

GHIMIRE B, LEE C AND HEO K. 2014. Leaf anatomy and its implications for phylogenetic relationships in Taxaceae s. l. J Plant Res 127: 373-388.

GNAEDINGER S. 2007a. Podocarpaceae woods (Coniferales) from middle Jurassic La Matilde formation, Santa Cruz province, Argentina. Rev Palaeobot Palynol 147: 77-93.

GNAEDINGER S. 2007b. Planoxylon Stopes, Protelicoxylon Philippe y Herbstiloxylon nov. gen. (Coniferales) de la Formación La Matilde (Jurásico Medio), provincia de Santa Cruz, Argentina. Ameghiniana 44: 321-335.

GNAEDINGER S. 2012. Ginkgoaleans woods from Middle Jurassic of the Argentina. Taxonomic considerations and palaeobiogeographical distribution. Geobios 45: 187-198.

GNAEDINGER S AND HERBST R. 2006. El género Prototaxoxylon Kräusel y Dolianiti (Taxales) de la Formación La Matilde (Jurásico Medio) del Gran Bajo de SanJulián, provincia de Santa Cruz, Argentina. Ameghiniana 43: 123-138.

HARRIS TM. 1935. The fossil flora of Scoresby Sound, East Greenland. Part 4: Ginkgoales, Coniferales, Lycopodiales and isolated fructifications. Medd Grønland 112: 3-172.

HERBST R. 2001. A revision of the anatomy of Millerocaulis patagonica (Archangelsky and de la Sota) Tidwell (Filices, Osmundaceae) from the Middle Jurassic of Santa Cruz province, Argentina. Asoc Paleont Argentina, Publicación Especial 8: 39-48.
HERBST R. 2003. Osmundacaulis tehuelchense nov. sp. (Osmundaceae, Filices) from the Middle Jurassic of Santa Cruz province (Patagonia, Argentina). Cour Forsch Inst Senckenberg 241: 85-95.

HIBBETT DS, DONOGHUE MJ AND TOMLINSON PB. 1997. Is Phellinites digiustoi the oldest Homobasidiomycete? Amer J Bot 84: 1005-1011.

HU YS AND YAO BJ. 1981. Transfusion tissue in gymnosperm leaves. Bot J Linn Soc 83: 263-272.

IBÁÑEZ C AND ZAMUNER AB. 1996. Presence of Hyphomycetes (Deuteromycetes) in cones of Araucaria mirabilis (Spegazzini) Windhausen, Middle Jurassic of Patagonia. Mycotaxon 59: 137-143.

JIN J, QIU J, ZHU Y AND KODRU TM. 2010. First fossil record of the genus Nageia (Podocarpaceae) in south China and its phytogeographic implications. Plant Syst Evol 285: 159-163.

KAUSIK SB. 1976. A contribution to foliar anatomy of Agathis dammara, with a discussion on the transfusion tissue and stomatal structure. Phytomorphology 26: 263-273.

KAUSIK SB AND BATTACHARYA SS. 1977. Comparative foliar anatomy of selected gymnosperms: leaf structure in relation to leaf form in coniferales and taxales. Phytomorphology 27: 146-160.

KIMURA T, OHANA T AND MIMOTO K. 1988. Discovery of a podocarpaceous plant from the Lower Cretaceous of Kochi Prefecture, in the Outer Zone of Southwest Japan. Proc Japan Acad 64: 213-216.

KLOSTER AC AND GNAEDINGER SC. 2018. Coniferous wood of Agathoxylon from the La Matilde Formation, (Middle Jurassic), Santa Cruz, Argentina. J Paleontol 92: $1-22$.

KRASSILOV VA. 1974. Podocarpus from the Upper Cretaceous of Eastern Asia and its bearing on the theory of conifer evolution. Palaeontology 17: 365-370.

KRÜSSMANN G. 1985. Manual of cultivated conifers. Portland: Timber Press, $361 \mathrm{p}$.

KUNZMANN L, MOHR BAR AND BERNARDES-DEOLIVEIRA MEC. 2004. Gymnosperms from the Lower Cretaceous Crato Formation (Brazil). I. Araucariaceae and Lindleycladus. Mitt Mus Nat kd Berl Geowiss Reihe 7: 155-174.

MASTROBERTI AA AND MARIATH JA. 2003. Leaf anatomy of Araucaria angustifolia (Bertol.) Kuntze (Araucariaceae). Revista Brasil Bot 26: 343-353.

MASTROBERTI AA AND MARIATH JA. 2008. Development of mucilage cells of Araucaria angustifolia (Araucariaceae). Protoplasma 232: 233-245.

MAZZONI MM, SPALLETTI LA, IÑIGUEZ RODRIGUEZ AM AND TERUGGI M. 1981. El Grupo Bahía Laura en el Gran Bajo de San Julián, Provinciade Santa Cruz. In: Actas 3 del $8^{\circ}$ Congreso Geológico Argentino, San Luis, Argentina, p. 485-507.

MENÉNDEZ CA. 1960. Cono masculino de una conífera fósil del Bosque Petrificado de Santa Cruz. Ameghiniana 2: 1117. 
MORTON S AND HERBST R. 2001. Nuevas especies del género Diplodon Spix (Bivalvia, Unionidea) del Jurásico Medio (Formación La Matilde), provincia de Santa Cruz, Argentina. Rev Mus Argentino Cienc Nat 3: 159-164.

MOTT KA, GIBSON AC AND O'LEARY JW. 1982. The adaptive significance of amphistomatic leaves. Plant Cell Environ 5: 455-460.

O'BRIEN TP AND MCCULLEY ME. 1981. The study of plant structure, principles and selected methods. Melbourne: Termercarphi Pty, 345 p.

OHANA T AND KIMURA T. 1993. Permineralized Brachyphyllum leafy branches from the Upper Yezo Group (Coniacian-Santonian), Hokkaido, Japan. Bull Natn Sci Mus Tokyo Ser C 19: 41-64.

OHSAWA T NISHIDA H AND NISHIDA M. 1995. Yezonia, a new section of Araucaria (Araucariaceae) based on permineralized vegetative and reproductive organs of A. vulgaris comb. nov. from the Upper Cretaceous of Hokkaido, Japan. J Plant Res 108: 25-39.

ORR MY. 1944. The leaf anatomy of Podocarpus. Trans Proc Bot Soc Edinburgh 34: 1-55.

PANZA JL AND IRIGOYEN MV. 1995. Hoja Geológica 4969-IV Puerto San Julián, escala 1:250.000, provincia de Santa Cruz. Boletín de la Dirección Nacional del Servicio Geológico 211: 1-78.

PARKHURST DF. 1978. The adaptive significance of stomatal occurrence on one or both surfaces of leaves. J Ecol 66: 367-383.

PHILIPPE M. 1993. Nomenclature générique des trachéidoxylesfossiles mésozoïques à champs araucarioïdes. Taxon 42: 74-80.

PHILIPPE M. 1995. Bois fossiles du Jurassique de Franche-Comté (nord-est de la France): systématique et biogéographie. Palaeontographica B 236: 45-103.

PHILIPPE M AND BAMFORD MK. 2008. A key to morphogenera used for Mesozoic conifer-like woods. Rev Palaeobot Palynol 148: 184-207.

PYYKKÖ M. 1966. The leaf anatomy of East Patagonian xeromorphic plants. Ann Bot Fenn 3: 453-622.

ROMBERGER JA. 1963. Meristems, Growth, and Development in Woody Plants: An analytical review of anatomical, physiological, and morphogenetic aspects. Ttech Bull US Dept Agr 1293: 1-214.

SACHER JA. 1955. Cataphyll ontogeny in Pinus lambertiana. Amer J Bot 42: 82-91.

SINGER R AND ARCHANGELSKY S. 1958. A petrified Basidiomycete from Patagonia. Amer J Bot 45: 194-198.

SEWARD AC AND FORD SO. 1906. The Araucarieae, recent and extinct. Phil Trans Roy Soc London B 198: 305-411.

SINGH H AND OWENS JN. 1982. Sexual reproduction in grand fir (Abies grandis). Can J Bot 60: 2197-2214.

SPALLETTI L, IÑIGUEZ RODRIGUEZ M AND MAZZONI M. 1982. Edades radimétricas de piroclastitas y volcanitas del Grupo Bahía Laura, Gran Bajo de San Julián, Santa Cruz. Rev Asoc Geol Arg 37: 483-485.

SPEGAZZINI C. 1924. Coniferales fósiles patagónicas. An Soc Cient Arg 98: 125-139.
STIPANICIC PN AND REIG OA. 1957. I. Parte Geológica. Consideraciones sobre el denominado "Complejo Porfírico de la Patagonia Extraandina". "Complejo Porfirico de la Patagonia Extraandina” y su fauna de anuros. Acta Geol Lill 1: 185-230.

STOCKEY RA. 1977. Reproductive biology of the Cerro Cuadrado (Jurassic) fossil conifers: Pararaucaria patagonica. Amer J Bot 64: 733-744.

STOCKEY RA. 1978. Reproductive biology of Cerro Cuadrado fossil conifers: ontogeny and reproductive strategies in Araucaria mirabilis (Spegazzini) Windhausen. Palaeontographica B 166: 1-15.

STOCKEY RA AND KO H. 1986. Cuticle micromorphology of Arancaria de Jussieu. Bot Gaz 147: 508-548.

STOCKEY R AND ATKINSON IJ. 1993. Cuticle micromorphology of Agathis Salisbury. Int J Plant Sci 154: 187-225.

STOCKEY RA, NISHIDA H AND NISHIDA M. 1994. Upper Cretaceous araucarian cones from Hokkaido and Saghalien: Araucaria nipponensis sp. nov. Int J Plant Sci 155: 806-815.

STULTS DZ, AXSMITH BJ, KNIGHT TK AND BINGHAM PS. 2012. The conifer Araucaria bladenensis and associated large pollen and ovulate cones from the Upper Cretaceous Ingersoll shale (Eutaw Formation) of Alabama. Cret Res 34: 142-148.

TAKASO T AND TOMLINSON PB. 1989. Aspects of cone and ovule ontogeny in Cryptomeria (Taxodiaceae). Amer J Bot 76: 692-705.

TAYLOR TN, TAYLOR EL AND KRINGS M. 2009. The biology and evolution of fossil plants. Amsterdam: Academic Press, $1253 \mathrm{p}$.

VOLKHEIMER W. 1969. Palaeoclimatic Evolution in Argentina and Relations with other Regions of Gondwana. In: Gondwana Stratigraphy, Earth Sciences 2, Actas IUGSUNESCO Symposium, Buenos Aires, 1967, p. 551-587.

VOLKHEIMER W, RAUHUT OWM, QUATTROCCHIO ME AND MARTINEZ MA. 2008. Jurassic Paleoclimates in Argentina, a review. Rev Asoc Geol Arg 63: 549- 556.

WILDE MH AND EAMES AJ. 1952. The ovule and seed of Araucaria bidwillii with discussion of the taxonomy of the genus. II. Taxonomy. Ann Bot 16: 27-47.

WOLTZ P, GAJARDO R AND FERREIRA AG. 1987. Anatomia comparada das folhas e evolução das Podocarpineae. Acta Bot Brasil 2: 77-99.

ZAMUNER AB AND FALASCHI P. 2005. Agathoxylon matildense n. sp., leño araucariaceo del Bosque Petrificado del cerro Madre e Hija, Formación La Matilde (Jurásico medio) provincia de Santa Cruz, Argentina. Ameghiniana 42: 339-346.

ZHOU Z. 1983. Stalagma samara, a new podocarpaceous conifer with monocolpate pollen from the Upper Triassic of Hunan, China. Palaeontographica B 185: 56-78. 